\title{
The Application of Micro - course in College English Teaching Weihua Zhan ${ }^{1, \text { a }}$ \\ ${ }^{1}$ Xi'an International University, Shaanxi, Xi'an, 710077 \\ aemail,
}

\author{
Keywords: Micro-Class; College English; Teaching Model; Teaching Means
}

\begin{abstract}
Traditional English teaching model in the new teaching environment also need to make new breakthroughs, teaching model also need to be more close to the status of contemporary university teaching development. In order to change the teaching limitations brought by the traditional English teaching mode, it is necessary to make students get better development and progress, improve the students 'overall quality, strengthen the students' English learning and carry out the new model of micro class. The application of English micro-class is not only the performance of classroom innovation, but also an important measure to improve students' interest in learning, improve teaching level and teaching efficiency. The author according to the relevant information discusses the current micro-class application for a more detailed discussion for the construction of college English classroom to provide help.
\end{abstract}

\section{Introduction}

In the current English teaching, or according to the text of the old set of models, stereotyped boring, so that students lose interest in learning. Pre-class preparation is not in place, the teaching content boring, redundant, in the amount of teaching content cannot do a good job of scientific planning, did not do a reasonable distribution of teaching content, resulting in teaching content is not too large capacity cannot be absorbed, A waste of time, cannot fully grasp the knowledge points, both of which directly lower the classroom teaching quality and teaching efficiency. The emergence of micro-class is to change the situation, not only in the content more rich, three-dimensional, intuitive and interesting, but also in the expression of the use of modern electronic technology equipment, this performance model is more close to contemporary college students Life, so that students can be more interested in the content of teaching. Micro-class short and pithy video content are related analysis so that students can quickly enter the learning state, but also more able to grasp the focus of learning.

\section{The Connotation and Characteristics of Micro Classes}

The Connotation of Micro Class. Micro-class is the use of related electronic equipment, some knowledge content video clips, the time is generally shorter, the conventional control in less than 10 minutes. Is to reduce the students' dependence on textbooks, so that students through the development of the times in line with the English learning, learning content and knowledge points for editing production, in the form of teaching video to students, so that students through a variety of channels for English learning, Not subject to geographical and time constraints, anytime, anywhere can be English learning. After taking the initial teaching video, and then in the classroom learning, teachers and students in the video content to discuss and deepen the expansion, we will jump out of the traditional teaching model of the new way called micro class. Is a special kind of education video as the carrier to streaming media for the transmission of a new type of teaching activities [1].

The Characteristics of Micro-Class. As a form of micro-class, the screen and the traditional blackboard teaching mode is different, more intuitive. Traditional teaching materials and teacher lectures have greater limitations, but the production of English teaching video, whether from the auditory, visual or other senses, have a more intense impact, can make people quickly into the state, and Put place in the transposition of thinking, with more powerful than the traditional model of 
appeal and persuasion [2]. In addition, the teaching video is more abundant and more comprehensive in the same time period than the traditional written course, and it is more extensive and comprehensive, and the general type of lecture video is shorter in time. The passing of the knowledge points are refined into the results after another refinement, so more professional and refined, so that students learn more easily grasp. In addition, the production of such teaching video generally does not appear other interference factors, will make students more focused, do not interfere with the impact of factors. And the video is more traditional mode, there is a bigger feature is to repeat the play, for the fuzzy point can be observed many times, so that learning more flexible and more efficient.

In the traditional teaching process, the first step is to explain the teacher's textbook knowledge, some professional knowledge points on-site direct teaching to complete the transmission of knowledge, followed by the second step is the students will be the classroom knowledge and content to absorb and digestive understanding, which is currently the general process of teaching English, this process for students is more restrictive, the students on the acceptance of knowledge is more unexpected, after-school digestion may also be a problem, for the focus of the omission will often happens. So that students through the teaching of video knowledge of the relevant point of learning, will be difficult, focus on the existing master, in advance to the knowledge system was built, and then through the original knowledge system based on classroom learning, this with a certain learning base of the great teaching To improve the efficiency of learning, so that students in the classroom focus on the difficulty of grasping, re-digestion and absorption, for the fuzzy point of the key memory, so that students learn more targeted and focused, greatly improving the efficiency of students learning. The construction of this new system for students to learn handy for the improvement of English has an important role [3].

\section{The Application Model and Advantages of Micro-Class in College English Teaching}

The Application Mode of Micro - course in College English Teaching. At present, the application of micro-class in college English teaching is divided into three modes: pre-class use of micro-class, the use of micro-class and after-school use of micro-class. Before the class, students learn micro-class, in advance with the new class related to the introduction and focus, difficulty introduction, will maximize the preview effect, thus reducing the teacher's time to explain the classroom. Class play with the classroom content of the higher degree of micro-class video, you can save teachers time and effort, leaving more teachers and students interactive and classroom activities of the time. After class, the classroom focuses on difficult to produce short and fine micro classes, to the student image analysis and induction, to improve the mastery of classroom content.

The above three kinds of application patterns throughout the teaching and learning process, improve classroom teaching efficiency. Although the micro-class will bring such a big change and advantages, but on the whole, the micro-class is still only a supplement to the existing teaching model, as a supplementary teaching exists [4].

The Advantages of Lesson in College English Teaching. The construction of the micro-class, whether in the teaching mode of innovation, or in the open space, are more than the traditional English teaching model has a huge change, this change can greatly attract the attention of students, micro-class for the interest The orientation is very large, only to fully stimulate the enthusiasm of students to learn interest in order to give full play to the students' subjective initiative, the passive to take the initiative, with less. Only when the students are interested, they will focus on learning, only the classroom vivid, in order to allow students to experience the joy of learning. English teaching knowledge points, wide coverage, practical and strong, teachers in a limited time to a large number of knowledge points to be transmitted, it is easy to cause the classroom boring, so that students get weariness. And especially in the moment, students for paper teaching visual fatigue make traditional English teaching more difficult. The construction of micro-class, can be more humane, close to the way students to knowledge points to talk about, to reduce the difficulty of teaching, improve the coverage of knowledge, make up for the limitations of traditional teaching, improve student interest.

At present, in English teaching, teaching methods of traditional single, or follow the traditional 
way of scripting, boring, poor flexibility. But the English language for the quality of the classroom requirements are very high, in the listening exercises and the English scene to restore, etc., so that video teaching is particularly important, it can have a clearer visual experience and hearing effects. English video has a more intuitive feel, the traditional teaching materials and teacher lectures have greater limitations, but the construction of micro-class, whether from the listening angle, visual or other senses have a more intense impact. It will allow students to more three-dimensional to observe, to think, so that students can quickly enter the state, but also to the professional English professional special can be closer to reality, with more than the traditional model of more appealing and persuasive. The micro-course plays an important role in the pre-class preview and the review of the post-class knowledge, so that teaching becomes a more open platform, and the obstacles from time and space are reduced.

\section{The Development Trend of Micro - course in College English Teaching}

From the Fragmentation Tends to Systematization. From the micro-class in our country "localization" date, college teachers produced English micro-class video has two main purposes the game and a single point of knowledge to explain, these videos did not form a complete system, but scattered in the various port. As the content of English learning, I believe that a single fine micro-course should be micro-curriculum development, the formation of content-related, interrelated, and independent of each other, and with appropriate exercises micro-courses [5].

From the System to the Platform. Scattered micro-class gradually formed a series of micro-courses, the teachers put forward higher requirements - to create a micro-class learning network platform, the micro-curriculum on the platform, sorting, to facilitate students to self-study.

Promote Resource Sharing Optimization. The systematicization of the micro-course is the resource base for creating the micro-course platform, and the platform development of the micro-class can promote the sharing of resources. English micro-class production content is numerous, the energy required should not be underestimated not a group or a group of teachers can be completed independently. Only the major colleges and universities to create an open platform for English learning, and teachers and students inside and outside the school to share high quality English micro-class resources in order to enrich and improve micro-courses, to maximize the sharing of resources, and even optimization.

\section{Conclusion}

In the current university classroom, with the implementation and promotion of the new curriculum reform, more and more educators recognize the importance of changing the educational idea and the transformation of the educational mode and realizing the importance of the innovation of English teaching methods. English teaching as an important part of the university curriculum, how to improve the quality of the classroom, change the traditional teaching mode, teaching methods of innovation has become the majority of mathematics teachers need to think about the problem, for the innovation of English teaching methods need to put more energy The The application of micro-class is not only the innovation of teaching methods but also the improvement of teaching mode, which can inject fresh blood into the current English teaching and improve the current teaching level.

\section{References}

[1] Xie Yichen. The application of micro-course in college English teaching - Taking Shenyang Physical Education Institute as an example [J]. Science and Technology Outlook, 2014, 15: 81.

[2] Chen Jingyan, Li Xin. On the application of micro-class in English teaching - A case study of the first foreign language mini-class competition in Hainan Province [J]. Journal of Hainan Radio \& TV University, 2015 , 03: 122-126. 
[3] Chen Xiangyun. Micro-class "micro-class" model in college English teaching [J].Journal of Hebei University of Engineering (Social Science Edition), 2015,04: 107-108 + 125.

[4] Wang Liang, Zhang Yumin, Peng Wangming, Hu Siqian. Micro-class in the university "organic chemistry" teaching application status and exploration[J]. New curriculum research (mid-term), 2016, 02: 7-9

[5] Wang Xinjie. Micro-class in college English teaching application [J]. Singapore Management and Sports Science Institute,Singapore.Proceedings of 2016 International Conference on Communication,Business and Education(CBE 2016 V50)[J].Singapore Management and Sports Science Institute,Singapore:,2016:4. 